\title{
Other Natural Hosts of Potato virus T
}

\author{
C. Lizárraga, M. Querci, M. Santa Cruz, I. Bartolini, and L. F. Salazar, Crop Protection Department, Interna- \\ tional Potato Center (CIP), Apartado 1558, Lima 12, Peru
}

\begin{abstract}
Lizárraga, C., Querci, M., Santa Cruz, M., Bartolini, I., and Salazar, L. F. 2000. Other natural hosts of Potato virus T. Plant Dis. 84:736-738.

Potato virus T (PVT), a member of the genus Trichovirus, was isolated from leaves of naturally infected ulluco (Ullucus tuberosus), oca (Oxalis tuberosa), and mashua (Tropaeolum tuberosum). These Andean tuber crops are often grown in small plots in association with potato (Solanum tuberosum) in the Peruvian highlands. PVT isolates from ulluco, oca, mashua, and potato infected virus-free ulluco, oca, and potato genotypes by mechanical inoculation. The incidence of PVT in mashua, oca, and ulluco accessions from the International Potato Center (CIP) in vitro germplasm bank was less than $10 \%$. A polymerase chain reaction (PCR) product of approximately $330 \mathrm{bp}$ was obtained from each of the four isolates using primers designed from the published PVT sequence. Restriction enzyme digestions of the PCR product did not demonstrate variability.
\end{abstract}

Additional keywords: seedborne viruses

In the Peruvian highlands, potato (Solanum tuberosum L., Solanaceae) often is grown in small plots in association with the other Andean tuber crops, ulluco (Ullucus tuberosus Caldas, Basellaceae), oca (Oxalis tuberosa Mol., Oxalidaceae), and mashua (Tropaeolum tuberosum R. \& P., Tropaeolaceae). Previous studies in Peru have demonstrated that some viruses can infect more than one of these crops. For example, Arracacha virus $B$ oca strain infects oca and potato (4). Potato black ringspot virus has been detected in oca (6) and the Andean root arracacha (Arracacia xanthorrhiza Bancroft, Umbelliferae) (7). Papaya mosaic virus infects both ulluco (2) and oca (1). Andean potato latent virus (8) and Potato leafroll virus (9) infect ulluco. This is the first report of other natural hosts of Potato virus $T$ (PVT), a member of the genus Trichovirus, which was first isolated from the Peruvian potato cv. Antarqui ( $S$. tuberosum subsp. tuberosum L. $\times S$. tuberosum subsp. andigena Juz. \& Buk.) and described by Salazar and Harrison (12). Viruses affecting Andean root and tuber crops are under study at the International Potato Center (CIP) to support efforts to produce propagation materials of better quality.

Corresponding author: C. Lizárraga

E-mail: c.lizarraga@cgiar.org

Accepted for publication 13 March 2000.

Publication no. D-2000-0508-03R

(c) 2000 The American Phytopathological Society

\section{MATERIALS AND METHODS}

Virus isolates and host plants. The PVT isolates used in this study are listed in Table 1. They were transferred by mechanical inoculation and multiplied in Chenopodium quinoa. The mashua isolate was from a naturally infected field plant. The oca and ulluco isolates were from the CIP in vitro germplasm collection. The potato isolate was the one described by Salazar and Harrison (12).

Host range. Host range studies were conducted in an insect-free greenhouse using virus-free plants obtained from meristem culture in cooperation with the Universidad Nacional de Cajamarca at Cajamarca, and the Universidad del Centro at Huancayo, Peru. All plants were inoculated mechanically by rubbing Carborundum-dusted leaves with $C$. quinoa sap extracts in $0.05 \mathrm{M}$ potassium phosphate buffer, pH 7.5. Experiments were performed twice.

Serology. Monoclonal mouse antiserum to PVT for double antibody sandwichenzyme-linked immunosorbent assay (DAS-ELISA) was provided by R. Burns (Scottish Agricultural Science Agency). The viral assays were performed according to Clark and Adams (3) using 0.01 M phosphate buffer, $\mathrm{pH} 7.4$, with $0.14 \mathrm{M}$ $\mathrm{NaCl}, 2 \%$ PVP-40, and $0.2 \%$ egg albumin as both extraction and conjugate buffers. Accessions from the in vitro germplasm bank at CIP were tested: 25 mashua accessions from Peru, and 374 ulluco and 220 oca accessions from Argentina, Bolivia, and Peru.

Virus purification and RNA extraction. C. quinoa leaves were harvested 14 to 21 days after inoculation. Fresh tissue was blended with 3.3 volumes of $0.1 \mathrm{M}$ citrate buffer, pH 6.2, with $0.01 \mathrm{M}$ EDTA, $1.5 \%$ Celluclast (Novo Industri A/S, Copenhagen, Denmark), and $0.1 \%$ thioglycolic acid (extraction buffer). After agitation for $2 \mathrm{~h}$ at room temperature, the homogenate was centrifuged at $8,000 \times g$ for $20 \mathrm{~min}$. The supernatant was emulsified with $25 \%$ chloroform and $n$-butanol (1:1) and centrifuged at $8,000 \times g$ for $20 \mathrm{~min}$. The supernatant was precipitated by $8 \%$ PEG 8000 with $1 \%$ $\mathrm{NaCl}$ by stirring for $1.5 \mathrm{~h}$ at $4^{\circ} \mathrm{C}$, and the mixture was centrifuged at $8,000 \times g$ for 30 min. The pellet was resuspended in a $1 / 10$ volume of $10 \mathrm{mM}$ sodium phosphate buffer, $\mathrm{pH} 7.6$, at $4^{\circ} \mathrm{C}$ overnight. The suspension was clarified by centrifuging at $11,000 \times g$ for $10 \mathrm{~min}$, and the virus was concentrated by centrifugation at 130,000 $\times g$ for $1 \mathrm{~h}$. Virus pellets were resuspended in the same buffer and further purified by sucrose density centrifugation at $160,000 \times$ $g$ for $45 \mathrm{~min}$. Gradients were fractionated at $254 \mathrm{~nm}$ with an ISCO (Instrument Specialties Co., Lincoln, NE) density gradient fractionator, and the virus was concentrated by centrifugation at $160,000 \times g$ for $1.5 \mathrm{~h}$. Virus concentration was estimated by ultraviolet absorbance spectroscopy using an extinction coefficient of 2.8 $\mathrm{cm}^{2} / \mathrm{mg}$ at $260 \mathrm{~nm}$ (12). Viral RNA was extracted by incubating $0.5 \mathrm{mg}$ of virus per $\mathrm{ml}$ with Proteinase K $(50 \mu \mathrm{g} / \mathrm{ml})$ and $0.1 \%$ sodium dodecyl sulfate (SDS) for $30 \mathrm{~min}$ at $37^{\circ} \mathrm{C}$, extracting with $0.1 \mathrm{M}$ Tris- $\mathrm{HCl}$, $\mathrm{pH}$ 8.0, buffered phenol, phenol-chloroform (1:1), and chloroform, and precipitating with $1 / 10$ volume of $0.5 \mathrm{M}$ sodium acetate, $\mathrm{pH} 5.4$, and 2.5 volumes of ethanol.

Reverse transcription-polymerase chain reaction (RT-PCR) procedures. Synthesis of cDNA was made using $1 \mu \mathrm{g}$ of purified viral RNA. The Gene Amp RNA PCR Kit (PE Applied Biosystems, Foster City, CA) was employed according to the manufacturer's protocol using oligo $\left(\mathrm{dT}_{16}\right)$

Table 1. Host sources and location of Potato virus $T$ (PVT) isolates used in this study

\begin{tabular}{lll}
$\begin{array}{l}\text { Tuber crop } \\
\text { isolate }\end{array}$ & \multicolumn{1}{c}{ Source $^{\mathbf{a}}$} & \multicolumn{1}{c}{ Location $^{\mathbf{b}}$} \\
\hline Mashua & cv. K'ello Zapallo & Puno, Puno \\
Oca & acc. MU-036 & Puno, Puno \\
Ulluco & acc. MH-463 & Cusco, Cusco \\
Potato & cv. Antarqui & $\begin{array}{c}\text { Llocllapampa, } \\
\text { Junín }\end{array}$ \\
\hline
\end{tabular}

a cv. = cultivar; acc. $=$ accession .

b Province, Department, Peru.

c International Potato Center (CIP) in vitro germplasm collection. 
primer. Primers PVT-1 $\left(5^{\prime}{ }_{989}\right.$ GACAAACGT CGGACTGATCTA) and PVT-2 (3' ${ }^{\prime}{ }_{1318}$ AGAGTGGCTTGGTCCAGTT) were purchased from GIBCO BRL (Rockville,
MD). Numbering is identical with the published PVT sequence (10). Amplification was then performed with $5 \mu$ of cDNA in a $20-\mu$ reaction mixture in a $1 \times$ reaction

Table 2. Reactions $\mathrm{s}^{\mathrm{a}}$ of potato, ulluco, oca, and mashua genotypes to mechanical inoculation with Potato virus $T$ (PVT) isolates

\begin{tabular}{|c|c|c|c|c|}
\hline \multirow[b]{2}{*}{ Species } & \multicolumn{4}{|c|}{ Isolates } \\
\hline & Potato & Ulluco & Oca & Mashua \\
\hline Solanum tuberosum (potato) & + & + & + & + \\
\hline cv. Amaryllis ${ }^{\mathrm{b}}$ & + & + & + & + \\
\hline cv. Canchan & + & + & + & + \\
\hline cv. Mariva & + & + & + & + \\
\hline cv. Revolucción & + & + & + & + \\
\hline cv. T. condemayta & + & + & + & + \\
\hline \multicolumn{5}{|l|}{ Ullucus tuberosus (ulluco) } \\
\hline acc. MH-290 & + & + & + & + \\
\hline acc. $013-\mathrm{U}-83$ & + & + & + & + \\
\hline acc. $055-\mathrm{U}-833$ & + & + & + & + \\
\hline acc. UA-104-84 & + & + & + & + \\
\hline \multicolumn{5}{|l|}{ Oxalis tuberosa (оса) } \\
\hline cv. Huanca & + & + & + & + \\
\hline cv. Zapalla & - & - & - & - \\
\hline acc. 065 & - & - & - & - \\
\hline \multicolumn{5}{|c|}{ Tropaeolum tuberosum (mashua) } \\
\hline cv. Zapallo & - & - & - & - \\
\hline
\end{tabular}

${ }^{a}$ Infection confirmed by double antibody sandwich-enzyme-linked immunosorbent assay (DASELISA) and back-inoculation to Chenopodium quinoa 2 to 3 and 3 to 4 weeks postinoculation, respectively.

${ }^{\mathrm{b}} \mathrm{cv} .=$ cultivar; acc. $=$ accession.

Table 3. Incidence of Potato virus T (PVT) infection among in vitro accessions in the International Potato Center (CIP) Germplasm Collection

\begin{tabular}{lcccc}
\hline & & \multicolumn{2}{c}{ No. of accessions $^{\mathbf{a}}$} & \\
\cline { 3 - 4 } Species tested & Country of origin & Tested & Infected & Incidence (\%) \\
\hline Tropaeolum tuberosum & Peru & 25 & 2 & $8.0(0-19.1)$ \\
Ullucus tuberosus & Argentina & 39 & 1 & $2.5(0-7.6)$ \\
& Bolivia & 77 & 6 & $7.8(1.7-13.9)$ \\
Oxalis tuberosa & Peru & 258 & 17 & $6.6(3.7-8.5)$ \\
& Argentina & 32 & 0 & $\ldots$ \\
& Bolivia & 41 & 0 & $\ldots$ \\
& Peru & 147 & 7 & $4.8(1.3-8.3)$ \\
\hline
\end{tabular}

a As determined by double antibody sandwich-enzyme-linked immunosorbent assay (DAS-ELISA) and mechanical inoculation to Chenopodium quinoa.

${ }^{\mathrm{b}}$ Numbers in parenthesis represent confidence limits $(P=0.05)$.

$\begin{array}{lllllll}1 & 2 & 3 & 4 & \text { W } & 5 & \text { L }\end{array}$

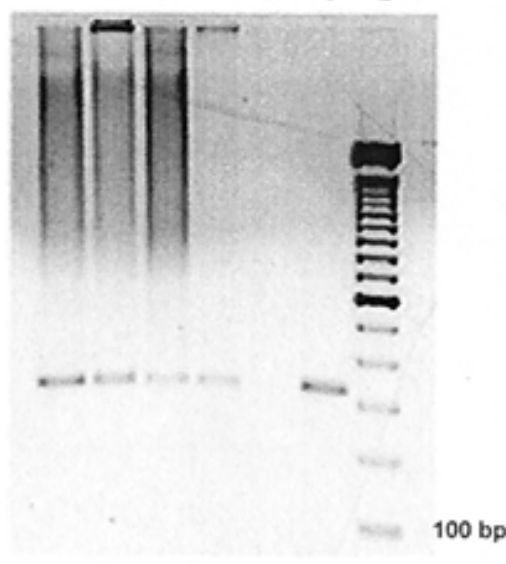

(
$\begin{array}{lllllll}\mathrm{L} & 1 & 2 & 3 & 4 & \mathrm{p} & 5\end{array}$

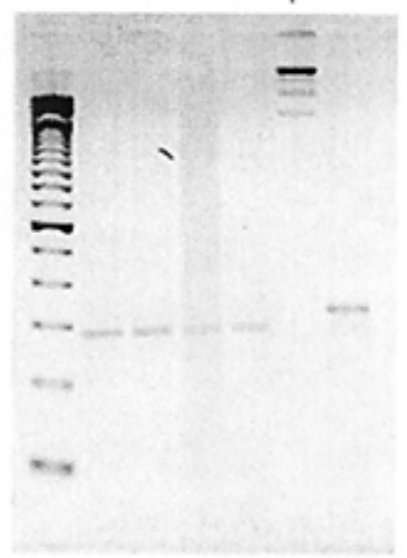

B buffer $(10 \mathrm{mM}$ Tris- $\mathrm{HCl}$, pH 8.3, $50 \mathrm{mM}$ $\mathrm{KCl}, 2.5 \mathrm{mM} \mathrm{MgCl}_{2}$ ) containing $0.625 \mathrm{U}$ $\mathrm{Taq}$ polymerase (Perkin-Elmer), and 10 pmole each of primers PVT-1 and PVT-2. The PCR was performed in a DNA Thermal Cycler 480 (Perkin-Elmer) for 35 cycles of $94^{\circ} \mathrm{C}$ for $1 \mathrm{~min}, 62^{\circ} \mathrm{C}$ for $2 \mathrm{~min}$, and $72^{\circ} \mathrm{C}$ for $1 \mathrm{~min}$. Amplified fragments were subjected to restriction enzyme digestions using DdeI, RsaI, and MseI (BRL) according to the manufacturer's protocols and visualized after electrophoresis in ethidium bromide-stained $1.5 \%$ agarose gels.

\section{RESULTS}

Host range. The four PVT isolates infected one oca and all the potato and ulluco genotypes tested. The mashua genotype was not infected (Table 2).

Virus incidence. PVT was detected in $8 \%$ of the mashua, $6 \%$ of the ulluco, and $3 \%$ of the oca in vitro accessions from the CIP Germplasm Collection (Table 3).

PCR and restriction enzyme digestions. The PCR product obtained from each of the four isolates was approximately $330 \mathrm{bp}$, and the fragments obtained from digestion with $R s a \mathrm{I}$ and $M s e \mathrm{I}$ were approximately $290 \mathrm{bp}$ and $215 \mathrm{bp}$, respectively. Two faint bands that could represent smaller fragments of less than $100 \mathrm{bp}$ were observed in the MseI digestion of the PCR products of the oca and mashua isolates (Fig. 1). Using the sequence data (10), the expected PCR product size was $330 \mathrm{bp}$, and the expected fragment sizes were $288 \mathrm{bp}$ and $42 \mathrm{bp}$ with RsaI, and $215 \mathrm{bp}, 65 \mathrm{bp}$, and $50 \mathrm{bp}$ with $M s e$ I. The visibility of PCR products or fragments in gels is dependent on their concentration. The smaller fragments from the digestions with $R s a \mathrm{I}$ and MseI were most likely not observed due to low concentration. There was no digestion with $D d e I$ (data not shown).

Fig. 1. Restriction enzyme digestions of polymerase chain reaction (PCR) products from Potato virus $T$ (PVT) isolates. (A) Undigested products, (B) RsaI, (C) MseI. 1 = potato, $2=$ ulluco, $3=$ oca, $4=$ mashua, $5=$ control potato (undigested), $\mathrm{W}=$ nuclease free water, $\mathrm{p}=$ plasmid $\mathrm{pBR} 322, \mathrm{~L}=$ ladder DNA 100 bp. 


\section{DISCUSSION}

Comparisons of the PCR product, restriction enzyme digestions and host range indicate that the PVT isolates from the four Andean tuber crops are similar. The positive DAS-ELISA reactions were of comparable intensity, and no difference in size was observed by SDS-polyacrylamide gel electrophoresis (PAGE) of the coat protein (data not shown). Failure to infect mashua and two oca genotypes could be due to resistance to PVT. Using mechanical inoculation, the mashua cultivar Zapallo was infected by isolates of Tropaeolum mosaic virus, and oca cultivar Zapalla and oca accession 065 were infected with an isolate of Potato black ringspot virus (C. Lizárraga, unpublished). No other virus-free mashua cultivar was available to test. Previously, other mashua and oca genotypes were infected by the potato PVT isolate by mechanical inoculation (12).

PVT is seed-transmitted in two families: Solanaceae ( $S$. tuberosum, Nicandra physalodes, and Datura stramonium) (12) and Chenopodiaceae (C. quinoa) (5). No vector has been reported (12). The incidence of PVT in the mashua, oca, and ulluco accessions tested here suggests that infection of these three Andean tuber crops is a rare event. In potato, PVT has only been found in Peru and Bolivia (11). Although PVT was detected in 15 of 30 native potato cultivars collected from Huaraz, Ancash (C. Lizárraga, unpublished), it is not commonly found in commercial potato cultivars in Peru. The true potato seed-borne nature of PVT and its presence in mashua, oca, and ulluco are important factors in the development of disease-free germplasm and the prevention of the spread of this virus from Bolivia and Peru.

\section{ACKNOWLEDGMENTS}

We thank R. Valdivia, CIRNMA, for the mashua cultivar K'ello Zapallo, and R. Orrego, CIP, for the PVT purification protocol. This work is part of the Collaborative Program for the Conservation and Use of the Biodiversity of the Andean Root and Tuber Crops and is supported by the Swiss Technical Cooperation.

\section{LITERATURE CITED}

1. Antola, A. 1994. Identificación y caracterización de un virus aislado de oca (Oxalis tuberosa Mol). Tesis para obtar el título de Biólogo. Univ. Nac. Agraria La Molina, Lima, Peru.

2. Brunt, A. A., Philips, S., Jones, R. A. C., and Kenten, R. H. 1982. Viruses detected in Ullucus tuberosus (Basellaceace) from Peru and Bolivia. Ann. Appl. Biol. 101:65-71.

3. Clark, M. F., and Adams, A. N. 1977. Characteristics of the microplate method of enzyme-linked immunosorbent assay for the detection of plant viruses. J. Gen. Virol.
34:475-483.

4. Jones, R. A. C. 1981. Oca strain of arracacha virus B from potato in Peru. Plant Dis. 65:753-754.

5. Jones, R. A. C. 1982. Tests for transmission of four potato viruses through potato true seed. Ann. Appl. Biol. 100:315-320.

6. Jones, R. A. C., and Kenten, R. H. 1979. A strain of arracacha virus B infecting oca (Oxalis tuberosa: Oxalidaceae) in the Peruvian Andes. Phytopathol. Z. 100:88-95.

7. Lizárraga, C., Chuquillanqui, C., and Jayasinghe, U. 1994. Un variante de del virus del anillo necrótico de la papa (Potato black ringspot virus, PBRV) aislado de arracacha (Arracacia xanthorrhiza). Fitopatología 29:144-149.

8. Lizárraga, C., Santa Cruz, M., and Jayasinghe, U. 1996. Detection of an isolate of Andean potato latent virus in ulluco (Ullucus tuberosus Caldas). Plant Dis. 80:344.

9. Lizárraga, C., Santa Cruz, M., and Salazar, L. F. 1996. First report of potato leafroll virus in ulluco (Ullucus tuberosus Caldas). Plant Dis. 80:344.

10. Ochi, M., Kashiwazaki, S., Hirasuka, K., Namba, S., and Tsuchizaki, T. 1992. Nucleotide sequence of the $3^{\prime}$-terminal region of potato virus T RNA. Ann. Phytopathol. Soc. Jpn. 58:416-425.

11. Salazar, L. F. 1995. Potato viruses and their control. International Potato Center, Lima, Peru.

12. Salazar, L. F., and Harrison, B. D. 1978. Host range, purification and properties of potato virus T. Ann. Appl. Biol. 89:223-235. 